\title{
The Promotion of Sustainable Development through Trade Instruments in the EU: Case Study for Ukraine
}

\author{
By Vesta Malolitneva ${ }^{1}$, Ruslan Dzhabrailov ${ }^{2}$
}

\begin{abstract}
Ukraine is lacking a systematic and comprehensive approach to achieving the goals of sustainable development in trade, since these goals are not integrated into the public policy-making process. The aim of this article is to analyze the European Union (EU) experience of using the trade instruments to implement sustainable development. The authors give special consideration to the use of the 'new generation' free trade agreements, which include the chapters devoted to sustainable development, in the EU. The Opinion of the European Court of Justice on the EU-Singapore free trade agreement in terms of sustainable development provisions is highlighted; since it may change the future EU trade policy and affect the EU's "soft" approach to the means ensuring the implementation of trade agreements, making the provisions of sustainable development agreements more effective. In this paper, we also explore the chapters of trade agreements on sustainable development, to which Ukraine is a party. Based on analysis of the EU trade policy, it is proposed to change the conceptual basis of implementing Ukraine's trade policy in order to achieve the sustainable development goals.
\end{abstract}

Keywords: sustainable development, trade policy, free trade agreement, generalized system of preferences, sustainability impact assessment, the EU, Ukraine.

\section{Introduction}

The 2015 UN Summit approved new benchmarks of the global development, namely 17 Sustainable Development Goals (United Nations, 2015). Ukraine, like the other UN Member States, joined the global process of ensuring the sustainable development. It requires conceptual changes in all aspects of life. The important role and impact on sustainable development is exercised by trade, particularly international trade in terms of globalization. While back in 1970 the trade accounted for less than 20\% of the global GDP, currently it represents a half of the world's GDP (European Commission, 2017). According to 17 Goals, trade should contribute to sustainable development. Although it is not indicated as a separate sustainable development goal, it is mentioned as a target within individual goals. For example, Goal 17 (Partnership) defines trade as a tool to achieve the sustainable development goals and calls for promotion of universal, rule-based, open, non-discriminatory and equitable multilateral trading system, and a significant increase in exports from developing countries. Despite all the positive aspects of globalization, which resulted in an active trade liberalization, it features some challenges. In May, 2017, the European Commission presented an analytical report on 'harnessing' globalization, which stresses not only the positive effects

1 $1 \mathrm{PhD}$., senior researcher at the Institute of Economic and Legal Research of the National Academy of Sciences of Ukraine, Kyiv

${ }^{2}$ Doctor of Law, deputy director at the Institute of Economic and Legal Research of the National Academy of Sciences of Ukraine, Kyiv 
of globalization, but also challenges, including for employment rate and environment (European Commission, 2017).

Trade liberalization may lead to lower standards of labour and environmental protection to reduce costs, for example by outsourcing to developing countries which raises the issue of fair working condition and 'fair trade' (Radin and Calkins, 2006). Typically, the immediate economic effects of increasing access to markets are estimated, and the longterm costs are ignored, including the limitation of regulatory policy autonomy. Thus, the trade development target may come into conflict with a number of targets inherent in the other sustainable development goals, for example to reduce the greenhouse gas emissions in economy within Goal 13 'Climate Action', since trade provides for one of the main components, i.e. transportation, increased movement of goods and services. In turn, transport is responsible for a significant share in greenhouse gas emissions (Sharma and Kumar, 2012; Essen, 2008). Therefore, sustainable development in the conventional sense of the interdependence of environmental, social and economic components, should be an integral part of the trade policy.

Despite the fact that a half of Ukraine's gross domestic product is generated by exports, Ukraine has not considered the issues of trade in the context of sustainable development, unlike the EU, where sustainability is an important element of the trade policy. Sustainable development is not listed among the strategic goals of trade development in Ukraine's Export Strategy (a "roadmap" of strategic trade development for 2017-2021) (The Cabinet of Ministers of Ukraine, 2017), in which it is mentioned only in the context of the need to develop and use innovations reducing the production negative impact on the environment. Besides, this issue is not considered in the Sustainable Development Strategy "Ukraine-2020" as the core document defining the long-term strategic development directions of Ukraine (The President of Ukraine, 2015). The above confirms the relevance of studying the problem of integrating the sustainable development goals into Ukraine's trade policy, taking into account the analysis of the foreign states' experience of introducing the best practices in this field, which will serve as the goal of this article.

\section{EU trade policy and the sustainable development}

EU pursues one of the most active policies in sustainable development implementation through trade. Thus, the EU Strategy "Trade for All" was adopted almost immediately after approval of the UN Sustainable Development Goals 2030, indicating the EU's focus on responsible trade as a sustainable development tool (European Commission, 2015).

The EU operates the Generalized System of Preferences (hereinafter - GSP) with respect to the import of goods originating from the least developed and developing countries and meeting certain criteria, including compliance with international standards in the field of environment and labor. The preferences can imply the exemption from customs duty or tariff reductions. Thus, a country willing to obtain these preferences must provide written evidence of the applying the legislation, e.g., in observance of labor rights, which embodies the standards stipulated by the relevant International Labor Organization (ILO) Conventions. Besides, certain incentives are provided when the 
country's legislation contains adequate environmental protection standards (Council of the European Union, 1998). GSP provides for suspension of preferences in case of violation of obligations. For example, the preferences were suspended in Belarus, Burma (now Myanmar) and Sri Lanka because of the labor rights violations (Lukas and Steinkellner, 2010). The purpose of these provisions is to help the GSP beneficiary countries to improve their environmental and social standards. These preferences are also considered as a compensation for additional costs of raising the countries' respective standards (Cuyvers, 2014). In 2014, a new GSP came into force (The European Parliament and the Council of the EU, 2012), which also provides incentives, but now subject to compliance with sustainable development goals based on an integrated approach, which is recognized in international conventions and specific instruments, such as the Rio de Janeiro Environment and Development Declaration 1992, Johannesburg Sustainable Development Declaration 2002, and others.

Besides, according to Part 5 of Article 3 of the EU Treaty, the Union in its relations with the world supports and promotes the planet sustainable development and free fair trade. It should be noted that the "fair and ethical" trade in the EU is seen as a sustainable development tool (CTA Brussels Office, 2008).

The EU introduced a special analytical and prognostic tool, Sustainability Impact Assessment, used by independent external experts during negotiations of trade agreements and for preliminary identification of their potential environmental, economic and social impact (Korol, 2013; European Commission, 2018). From 1999 to March 2016, the EU has made more than 20 assessments of international trade impact on sustainable development (European Commission, 2016), including the assessment during negotiations of a free trade area within the EU-Ukraine Association Agreement (European Commission, 2009). This assessment provides for a report on the potential economic, social and environmental agreement impact and development of recommendations to improve its provisions. The recommendations based on the results of assessing the international trade impact on sustainable development during negotiations of the free trade area within the EU-Ukraine Association Agreement provided for inclusion of a separate chapter into the Agreement, which is dedicated to sustainable development in the context of trade liberalization.

Ukraine does not conduct a separate assessment of the trade impact on sustainable development. Although paragraph 139 of the Preliminary Action Plan on the EUUkraine Association Agreement Implementation 2014 (The Cabinet of Ministers of Ukraine, 2017) provided for submission of the methodology of assessing the trade impact on sustainable development in December 2017 and carrying out this assessment in December 2018 by the relevant ministries, the said methodology has not been developed. Currently, a new Action Plan to Implement the EU-Ukraine Association Agreement (The Cabinet of Ministers of Ukraine, 2017) does not provide for development of such a methodology and assessment of the trade impact on sustainable development; it only indicates a need to develop and submit a bill on strategic environmental assessment (which is adopted already).

Another means of integrating the Sustainable Development Goals into the EU trade policy is inclusion of sustainable development commitments into the free trade agreements with the third countries. Making sustainable development one of the main 
goals of the EU trade policy, the European Commission has established an objective to include separate chapters on sustainable development in free trade agreements (European Commission, 2015).

Although the free trade agreements containing the sustainable development principles date back to the 1990's, the search for a more systematic and coherent approach to sustainable development in EU trade agreements was started much later, in the late 2000's. The inclusion of the common trade policy into the goals and principles of the EU external action under the Lisbon Treaty has led to changes in this area by transition to a more value-oriented approach towards the trade policy (Bahar, 2018). The European Parliament takes a proactive stance to inclusion of sustainable development provisions in the EU common trade policy, including the trade agreements. In its Resolution 2010, it calls the European Commission to include a number of international social and environmental protection standards in all free trade agreements being negotiated in a consistent manner (The European Parliament, 2010).

The first agreement, which included the sustainable development provisions, was a free trade agreement between the EU and the Republic of Korea. A separate sustainable development chapter is envisaged in the EU Association Agreement with the Central America. Recently, the EU and Japan finalized negotiations on Economic Partnership Agreement, where a separate chapter is devoted to sustainable development. On September 21, 2017, the Comprehensive and Economic Trade Agreement between the EU and Canada came into force, Chapter 22 of which is devoted to sustainable development problems based on an integrated approach of interdependence of the three sustainable development components. Besides, the EU signed free trade agreements containing the sustainable development commitments with Vietnam, Colombia, Peru and Ecuador.

Such agreements are called 'the new generation' agreements, i.e. trade agreements, which include, besides conventional agreement elements, such as the reduction or elimination of tariffs and non-tariff barriers, the other elements related to or even inseparable from trade. Most of these agreements provide for mutual commitments to develop and promote trade and economic relations so as to encourage sustainable development. The basic commitments require each party to create its own level of protecting the environment and labor rights and to adopt or modify its regulations or policies in line with the internationally recognized principles of environmental and labor standards or agreements to which the country is a party. These separate sections or chapters can also contain some commitments, for example, related to timber trade and fish products. Usually, these provisions do not provide for substantially new commitments in the field of environmental protection and labor rights, but usually confirm certain existing international commitments. Their aim is to ensure the absence of adverse impact on trading and investments conditions because of different protection levels. In these agreements, the EU places equal importance on the labor and environment protection (European Commission, 2017).

An important role in confirming the relationship between sustainable development and common commercial policy is played by the Opinion 2/15 of the EU Court of Justice dated 16 May 2017 (Court of Justice, 2017). In connection with the EU's negotiations of a free trade agreement with Singapore, the European Commission requested the Court 
to issue an opinion on the EU competence in conclusion of this agreement. The Court notes that the EU Treaty and the Treaty on the Functioning of the EU (TFEU), which came into force on December 1, 2009, are very different from the previous EU Treaties in the context of the common commercial policy, and include new aspects of modern international trade. According to the Court, one of the most important innovations is the TFEU provision enshrined in Part 1 of Article 207, according to which the common trade policy shall be implemented in the context of principles and objectives of the Union external activities. These principles and objectives are enshrined in Article 21 of the EU Treaty, including the promotion of sustainable development of the economy, society and environment in developing countries in view of the main goal, to eradicate poverty and to promote the development of international measures to preserve and improve the environment and reasonable management of the world's natural resources to ensure sustainable development. EU's commitments to integrate these principles and goals in the implementation of the common commercial policy are obvious. Thus, according to Part 3 of Article 21 of the EU Treaty, the Union adheres to the principles and relentlessly follows the objectives set out in Parts 1 and 2 during the development and implementation of various directions of its external activities covered by this chapter and Part 5 of the TFEU. In its turn Part 5 of the TFEU discusses the issues of a common commercial policy. The same is confirmed by Article 205 of the TFEU, according to which the Union activities on the international scene are guided by the principles, pursue the goals and are implemented according to the terms set out in Chapter I of Section V of the EU Treaty. Chapter 1 of the said section includes Article 21, establishing the principles and objectives of the Union external activities. It is also important to pay attention to Articles 9 and 11 of the TFEU, which describe an important role of environmental protection requirements, promoting a high level of employment, and availability of adequate social protection safeguards in the implementation of the Union policies and actions. Therefore, the Court concluded that sustainable development is an integral part of the common commercial policy, thereby confirming a new EU's value-oriented approach to the trade policy.

However, a dissenting opinion was expressed by Advocate General, who considers that these provisions fail the test to "be determined as measures which are not purely economic by nature, but still fall within the scope of the common trade policy" (Advocate general Sharpston, 2016). The Advocate argues that some provisions related to the sustainable development activities do not promote, do not facilitate or do not govern trade and have no direct and immediate effect thereon. That is, they do not regulate the use of the trade policy tools to implement the sustainable development. The free trade agreement provisions establish the minimum standards of environmental protection and labor rights in isolation from their possible effects on trade, so they are not covered by the EU common commercial policy.

Still, supporting the position of the Court, such sustainable development provisions have an impact on trade, because they reduce the risks of significant differences between production costs in the countries, which are the parties to the free trade agreement. This will facilitate the participation of undertakings in free trade on equal terms. Besides, environmental standards are often used as an indirect means of protecting markets and trade barriers. Indeed, the contradictions in the level of environment and labor rights 
protection between countries can have a direct impact on international trade. Lower protection standards of one party can increase trade and investment in its territory. As Canada often notes in trade agreements, the countries may provide that a dispute can be raised only if the party is able to prove that a violation, e.g. of the labor standards, is related to trade. A fine for violation would be equivalent to the negative trade effects, i.e. the fine calculation requires quantification of the impact on trade.

Currently, the EU keeps discussing a 'soft' approach and a rather declarative nature of sustainable development provisions in the EU free trade agreements because of the lack of effective mechanisms to ensure their implementation, in contrast to the mechanisms provided for the trade liberalization commitments (Harrison et. al., 2018; Transport\&Environment, 2017). The problem of such agreements is considered a lack of responsibility and focus mainly on the mutually agreed solutions to the problems, which arise, while they typically provide for a two-tier (1 - consultations, 2 - creation of an expert group that would help find a solution) procedure to settle disputes between states. However, this procedure is separated from the general mechanism to settle the disputes under the agreement, which provides for a compensation for its breach. Although the development of a new separate dispute resolution procedure adds importance to the sustainable development provisions in agreements, the system still remains 'soft' and not legally binding. However, in 2017 the European Commission started discussions to improve the implementation and fulfillment of sustainable development commitments contained in the free trade agreements (European Commission, 2017). Some authors suggest making the trade liberalization dependent on the state of compliance with sustainable development requirements and introducing specific sanctions for noncompliance (Harrison et. al., 2018). Besides, an important role in this regard should be played by the above Opinion, in which Court of Justice refers to Part 1 of Article 60 of the 1 Vienna Convention on the Law of Treaties, according to which, in the event of breach of the social and environmental protection commitments provided for in a Free Trade Agreement with Singapore, the parties shall be entitled to terminate or stop trade liberalization. Such a position of the Court can subsequently enhance the implementation of sustainable development provisions and create incentives for compliance with sustainable development provisions provided for in trade agreements.

\section{Ukrainian trade policy and the sustainable development}

The most recent free trade agreements with Ukraine also contain specific provisions on sustainable development, although to varying degrees. The Free Trade Agreement with the European Free Trade Association countries, signed in 2010, in its final provisions provides for a commitment to revise the agreement by the Joint Committee three years after its entry into force in the background of changes in trade and sustainable development. The Agreement entered into force in 2012, though the data on its revision in connection with sustainable development are missing. Thus, in the context of sustainable development, this Agreement is declarative in nature, consolidating its intentions and commitment to social and economic development, health and safety, ensuring the fundamental rights of workers, including the principles established by the relevant Conventions of the ILO; a decision to perform the agreement 
for environment conservation and protection in the Preamble only. That means that the Agreement does not provide for specific commitments and measures to protect the environment and labor rights.

The EU-Ukraine Association Agreement contains Chapter 13 devoted to issues of trade and sustainable development and indicates a commitment to the effective implementation of fundamental ILO Conventions and multilateral agreements on environmental protection. Some provisions are defined on the timber trade and fish products. This chapter identifies institutional mechanism for implementing these provisions. In May 2017, the first meeting of Ukraine-EU Subcommittee on Trade and Sustainable Development created pursuant to Article 300 of Chapter 13 was held, which discussed the issues related to fulfillment of commitments contained in this chapter of the Agreement. However, based on analysis of the Agreement provisions related to trade and sustainable development it is impossible to determine the consequences of their non-implementation or violation. For example, Article 301 provides for the right to convene the group of experts to examine the matter, which was not satisfactory addressed through governmental consultations. This group shall submit a report to the agreement parties, and the parties shall endeavor to accommodate advice or recommendations of the group, however, the Agreement does not provide for anything in the case where the parties fail to fulfill these recommendations.

The Free Trade Agreement between Canada and Ukraine, despite the fact that the concept of 'sustainable development' is not explicitly mentioned in the text, contains separate chapters providing for certain commitments in the field of environmental protection and labor (Chapters 12 and 13). It should be noted that Chapter 13, including Annex 13-C, devoted to the labour issues, provide for financial penalties, which may not exceed USD 15 million annually. Establishment of a specific liability is an effective means, addressing the issue of the largely declarative nature of sustainable development provisions in free trade agreements. However, no specific sanction is provided for breach of environmental regulations. Although the Agreement establishes a dispute settlement procedure, however, with a focus on solving the problems through consultations at different levels, first at the level of the Environment Committee, composed of the parties; representatives, and then at the ministerial level. In the event of failure to settle the issue, a review panel shall be established, which shall develop a final report, according to which the parties have to agree on a mutually acceptable action plan to address the problem. This plan should be communicated to the public. However, the consequences of the action plan failure are not established.

Importantly, the provisions on sustainable development in these trade agreements are the result of requirements and practices of the countries with which the agreement was signed, and not of Ukraine (Resource and Analytical Center 'Society and Environment', 2017). Based on the analysis of provisions on the protection of labor rights and environment, we can conclude that the states, which are parties to the Agreement, dictate their conditions. For example, Canada in its trade agreements with the other countries uses sanctions in the form of a fine. If we compare the provisions of the Free Trade Agreement between Canada and South Korea, we can conclude an almost the same structure and content of the chapter on protection of labor rights, as provided for in the Free Trade Agreement with Ukraine, with the exception of certain provisions on liability 
for breach of commitments. The same is true for the EU trade agreements, e.g. the provisions of the Free Trade Agreement with South Korea are almost identical to the provisions contained in the Association Agreement with Ukraine. It means that Ukraine does not consider sustainability as an integral part of the national trade policies and does not have its own approach to the integration of sustainable development in trade. The lack of own position can lead to significant regulatory restrictions in the future due to assumed commitments. Therefore, one should note the position of some authors who believe that bilateral free trade agreements, even more than the multilateral international regulations, may restrict the ability of the governments to take steps to enhance the social policies or improve the environmental protection (Orbie et al., 2016). Thus, Ukraine, having the priorities enshrined in strategic documents and a systematic approach to integrating the sustainable development goals into its trade policy can defend its own interests, and not only take the position of its trading partner.

\section{Conclusions}

1. It is required to change the conceptual basis of the trade policy implementation to achieve the sustainable development goals. Trade policy should be implemented so as to focus not only on reducing costs and obtaining immediate benefits, but also to support the long-term objectives of the state.

2. Ukraine is lacking a systematic and comprehensive approach to achieving the sustainable development goals in trade, because the sustainable development goals are not integrated into the public policy-making process. The strategic documents of Ukraine, including the Sustainable Development Strategy of Ukraine 2020 and Ukraine's Export Strategy should clearly stipulate the provision on sustainable development as an integral part of trade and trade as a means of achieving the sustainable development.

3. Sustainable development issues should be an integral part of negotiations to conclude the further trade agreements. Value-oriented approach should be the basis of decisions to conclude the new trade agreements. However, Ukraine should develop its approach to the relationship between sustainable development and trade, in order to include the issues relevant for our country, not just for the other party, in free trade agreements. That means it is important not to join the existing provisions on sustainable development of the trading partner, but to propose one's own provisions based on the features of the national economic, environmental and social policies. During the negotiations, Ukraine should proceed from its strategic socio-economic development goals, an integral part of which should be the sustainable development goals. The future trade agreements should provide for specific measures and liability for their failure in order to shift from declaratory to effective mechanism.

4. Ukraine does not conduct a separate assessment of the trade impact on sustainable development, which requires the development of a methodology to assess the sustainable development impact on trade, and performance of such an assessment during negotiations to conclude trade agreements. Besides, this methodology should provide for mandatory tracking of the agreement deliverables (ex-post assessment) with a view to making appropriate changes by enshrining the provision on the potential agreement revision in view of development of sustainable development and trade relations. 


\section{References}

Agreement establishing an Association between the European Union and its Member States, on the one hand, and Central America on the other. Official Journal of the European Union, 15 December 2012, L 346: 3.

Advocate general Sharpston (2016). Opinion of on 21 December 2016. Request for an Opinion pursuant to Article 218(11) TFEU - Conclusion of the Free Trade Agreement between the European Union and the Republic of Singapore - Allocation of competences between the European Union and the Member States. Available at::

http:/ $/$ curia.europa.eu/juris/document/document.jsf?text $=\&$ docid $=186494 \& p a g e I n d e x=0 \& d o c l$ ang=EN\#Footref370 (accessed 12 April 2018).

Association Agreement between the European Union and its Member States, of the one part, and Ukraine, of the other part. Official Journal of the European Union, 29 May 2014, L 161: 3.

Bahar, G. (2018). EU competences on trade policy: Opinion 2/15 and prospects for future EU trade agreements. Available at: http://www.ikv.org.tr/images/files/EU\%20Trade\%20Policy\%20Competences\%20Jan2018Bahar Guclu(1).pdf (accessed 13 April 2018).

Canada-Korea Free Trade Agreement. Available at: http://international.gc.ca/trade-commerce/trade-agreementsaccords-commerciaux/agr-acc/korea-coree/fta-ale/18.aspx?lang=eng (accessed 19 April 2018).

Canada-Ukraine Free Trade Agreement. Official Bulletin of Ukraine. 2017. №30.

Court of Justice (2017). Opinion 2/15 of the Court (full Court) of 16 May 2017. Available at: http://curia.europa.eu/juris/document/document.jsf?text $=\&$ docid $=190727 \& p a g e I n d e x=0 \& d o c l$ ang $=$ EN\&mode $=1$ st\&dir $=\& o c c=$ first\&part $=1 \& c i d=882092$ (accessed 12 April 2018).

Council of the European Union (1998). Applying a multiannual scheme of generalised tariff preferences for the period 1 July 1999 to 31 December 2001. Regulation № 2820/98 of 21 December 1998. Official Journal of the European Union, 30.12.1998, L 357: 1.

CTA Brussels Office (2008). Does Fair Trade contribute to sustainable development? Available at: https://brusselsbriefings.files.wordpress.com/2012/10/br-5-reader-br-5-fair-trade-eng.pdf (accessed 1 February 2018).

Cuyvers, L. (2014). The sustainable development clauses in free trade agreements of the EU with Asian Countries: perspectives for ASEAN? Journal of Contemporary European Studies, 22(4). Available at: https://www.tandfonline.com/doi/abs/10.1080/14782804.2014.923752 (accessed 11 April 2018).

Economic Partnership Agreement between the EU and Japan. Available at: http://trade.ec.europa.eu/doclib/docs/2017/december/tradoc 156444.\%2020171207\%20EUJP\%20TSD\%20Chapter\%20Final.pdf (accessed 8 April 2018).

EFTA-Ukraine Free Trade Agreement. Official Bulletin of Ukraine. 2012. № 1/№54.

European Commission (2009). Trade sustainability impact assessment of the negotiations on a free trade area between the EU and Ukraine: Position Paper. Available at: http://trade.ec.europa.eu/doclib/docs/2009/mav/tradoc 143165.pdf (accessed 10 November 2017).

European Commission (2015). Trade for all. Towards a more responsible trade and investment policy. Available at: http://trade.ec.europa.eu/doclib/docs/2015/october/tradoc 153846.pdf (accessed 9 April 2018).

European Commission (2016). Handbook for trade sustainability impact assessment: second edition. Available at: http://trade.ec.europa.eu/doclib/docs/2016/april/tradoc 154464.PDF (accessed 10 November 2017).

European Commission (2017). Reflection paper on harnessing globalization. COM(2017) 240. Available at: https://ec.europa.eu/commission/sites/beta-political/files/reflection-paper-globalisation en.pdf (accessed 9 April 2018).

European Commission (2017). Trade and Sustainable Development (TSD) chapters in EU Free Trade Agreements (FTAs). URL: http://trade.ec.europa.eu/doclib/docs/2017/july/tradoc_155686.pdf (accessed 13 April 2018).

European Commission (2018). Sustainability Impact Assessment. Available at: http://ec.europa.eu/trade/policy/policy-making/analysis/policy-evaluation/sustainability-impactassessments/index en.htm (accessed 10 November 2017). 
Free trade agreement between the European Union and its Member States, of the one part, and the Republic pf Korea, of the other part. Official Journal of the European Union, 14 May 2011, L 127: 6.

Harrison, J., Barbu, M., Campling, L., Richardson, B., Smith, A. (2018). Governing Labour Standards through Free Trade Agreements: Limits of the European Union's Trade and Sustainable Development Chapters. Journal of Common Market Studies. Available at: https://onlinelibrary.wiley.com/doi/abs/10.1111/jcms.12715?af $=\mathrm{R}$ (accessed 5 April 2018).

Korol, V. (2013). Legal determinants and barriers for implementation of export strategies of the parties of Ukraine's foreign economic activity within the free trade areas with the EU and CIS countries. Available at: https://drive.google.com/file/d/0BwuVse3YcpX9azlMaUw0WTR1TVE/view (accessed 15 November 2017).

Lukas, K. and Steinkellner, A. (2010). Social standards in sustainability chapters of bilateral free trade agreements. Ludwig Bolzmann Institute of Human Rights. Available at: https://media.arbeiterkammer.at/wien/PDF/studien/Studie_Nachhaltigkeit englisch.pdf (accessed 13 April 2018).

Radin, T.J. and Calkins, M. (2006). The Struggle Against Sweatshops: Moving Toward Responsible Global Business. Journal of Business Ethics, 66 (2-3): 261-271.

Resource and Analytical Center 'Society and Environment (2017). Environmental issues in trade policy of the EU and Ukraine: the path to sustainable development. Available at:

http://www.rac.org.ua/uploads/content/405/files/webenvironmentalissuessocietyandenvironme nt2017ua.pdf (accessed 19 April 2018).

Sharma, R.K. and Kumar, S. (2012). Impact of Transportation System on Environment in Developing Countries "A Review". International Journal of Research Review in Engineering Science and Technology, 1(2): 61-66.

The Cabinet of Ministers of Ukraine (2017). Export Strategy of Ukraine 2017-2021 (roadmap on strategic development of trade). Official Bulletin of Ukraine. 2018. №11.

The Cabinet of Ministers of Ukraine (2014). On the implementation of the Association Agreement between Ukraine, on the one hand, and the European Union, the European Atomic Energy Community and their Member States, on the other hand (expired). Official Bulletin of Ukraine. 2014. № 77.

The Cabinet of Ministers of Ukraine (2017). On the implementation of the Association Agreement between Ukraine, on the one hand, and the European Union, the European Atomic Energy Community and their Member States, on the other hand. Official Bulletin of Ukraine. 2018. № 24.

The Comprehensive and Economic Trade Agreement (CETA). Available at: http://ec.europa.eu/trade/policy/in-focus/ceta/ceta-chapter-by-chapter/ (accessed 8 April 2018).

The European Parliament (2010). Resolution of 25 November 2010 on human rights and social and environmental standards in international trade agreements. Available at:

http:/ $/$ www.europarl.europa.eu/sides/getDoc.do?type $=$ TA\&language $=E N \&$ reference $=$ P7-TA2010-434 (accessed 9 April 2018 p.).

The European Parliament and the Council of the EU (2012). Applying a scheme of generalised tariff preferences and repealing Council Regulation (EC) № 732/2008: Regulation № 978/2012 of 25 October 2012. Official Journal of the European Union, 25 October 2012, L. 303: 1.

The President of Ukraine (2015). Strategy on Sustainable Development "Ukraine-2020". Official Bulletin of Ukraine. 2015. №4.

Transport\&Environment (2017). Trade and Sustainable Development: a chance for innovative thinking. Available at:

https://www.transportenvironment.org/sites/te/files/publications/2017_10 Trade_sustainable development final.pdf (accessed 5 April 2018).

Orbie, J., Martens, D., Oehri, M., Putte, L. (2016). Promoting sustainable development or legitimising free trade? Civil society mechanisms

in EU trade agreements. Third World Thematics: A TWQ Journal, 1(4): 526-546.

United Nations (2015). Sustainable development goals. Available at: https://www.un.org/sustainabledevelopment/sustainable-development-goals/ (accessed 17 April 2018).

Van Essen, H. (2008). The Environmental Impacts of Increased International Road and Rail Freight Transport. Available at: http://www.oecd.org/greengrowth/greening-transport/41380980.pdf (accessed 20 April 2018). 